\title{
Electrochemical Behavior of stainless steel AISI 430 exposed to simulated food
}

\author{
Anderson Sandoval-Amador ${ }^{1}$, Jhon Edisson Torres-Ramirez ${ }^{2}$, \\ Diana Yiseth Vargas-Castro ${ }^{1}$, Jhonatan Ramiro Caceres-Nuñez ${ }^{1}$, \\ Hugo Armando Estupiñan-Duran ${ }^{3}$, Darío Yesid Peña-Ballesteros ${ }^{1}$
}

\footnotetext{
${ }^{1}$ Grupo de Investigaciones en Corrosión GIC, Universidad Industrial de Santander UI, Bucaramanga, Colombia. e-mail: anderson84f@gmail.com,dypena@uis.edu.co

${ }^{2}$ Comisión Nacional de Energía Atómica, Universidad Nacional de San Martin, Buenos Aires, Argentina.

e-mail: jtorram@gmail.com

${ }^{3}$ Grupo de Tribología y Superficies GTS, Universidad Nacional, Medellín, Colombia

e-mail: haestupinand@unal.edu.co
}

\begin{abstract}
Due to the excellent properties of stainless steel, these materials have a variety of applications among which is the food processing industry. One of the main problems in this industry is the possible releasing of metal ions towards food. For this reason, it is very important to know corrosion behavior of steels that are used in this industry. In this study the release of $\mathrm{Fe}, \mathrm{Cr}$ and $\mathrm{Ni}$ ions and the electrochemical behavior of AISI 430 steel with three different surfaces finishes in contact with a solution that simulates food contact (acetic acid $3 \% \mathrm{v} / \mathrm{v}$ ) was evaluated. For this, the influence of the surface finish (polished by SiC paper 600, 1200 and 1500 grit) and the exposure time to the solution (4 and 10 days) at different temperatures $\left(25,60\right.$ and $\left.100^{\circ} \mathrm{C}\right)$ was analyzed by atomic absorption spectroscopy, linear polarization resistance and potentiodynamic polarization curves. The results show that the releases of $\mathrm{Fe}, \mathrm{Cr}$ and $\mathrm{Ni}$ ions, the linear polarization resistance and the corrosion rate of the AISI 430 steel depend on surface finish and temperature. The lower corrosion rate was obtained when the material had the smooth surface finish, in such a way that it is possible to avoid health risks due to the release of metal ions.
\end{abstract}

Keywords: Metal release, surface finish, acetic acid, food contact, corrosion.

\section{INTRODUCTION}

Stainless steel has excellent properties, which include high corrosion resistance at high and low temperatures, mechanical and physical properties, durability, easy cleaning and recycling It, is also aesthetically attractive since it can keep its luster and natural color. For that reason, stainless steel has a wide range of applications ranging from skyscrapers, medical implants to diverse food-related applications.

In applications where stainless steel comes into direct or indirect contact with human, such as food processing, required a wide variety of studies that allow to understand the performance that these materials will be at the time to be put into service [1-4]. Therefore, for the food industry the study of the performance of stainless steels which are in contact with food is of a great interest, since it may lead to leaching of metal ions to food and this will cause adverse effects on human health [5]. According to the above, several works have been developed in order to understand the behavior of stainless steel in contact with food [6-12].

The Italian Ministerial Decree of March 21, 1973 is one of the more detailed documents on the regulation of the global release of metal ions. According to this text, the most relevant components of stainless steel, whose release must be considered to be in contact with food are $\mathrm{Fe}, \mathrm{Cr}$ and $\mathrm{Ni}$ [13].

Chromium is an essential element necessary for the metabolism of fats and sugar. The daily dietary intake of $\mathrm{Cr}$ (III) estimated is 50 to $200 \mu \mathrm{g}$ for human, and there are no toxic effects documented in nutritional studies at levels of up to $1 \mathrm{mg}$ per day. The World Health Organization (WHO) has established the $\mathrm{Cr}$ (IV) maximum value at $0.05 \mathrm{mg} / \mathrm{L}$ in drinking water due to the $\mathrm{Cr}$ (IV) be carcinogenic $[5,12,14,15]$.

Nickel is a key component of stainless steels, specially austenitic and duplex ones, whose effects on human health are mainly related to allergic reactions. The average daily intake of $\mathrm{Ni}$ is estimated around 0.2 $\mathrm{mg} /$ day $[5,12,15,16]$.

According to the Italian Decree, it is possible to use a $3 \% \mathrm{v} / \mathrm{v}$ acetic acid solution to simulate contact 
with food. For this reason, to carry out this study, this solution was used as electrolyte in the ion release tests and the electrochemical tests to determine the corrosion behavior of AISI 430 steel.

\section{MATERIALS AND METHODS}

\subsection{Sample preparation}

Samples were cut from AISI 430 steel with approximate dimensions of $20 \mathrm{~mm}$ x $20 \mathrm{~mm}$ x $0.45 \mathrm{~mm}$. The grinding was performed using $\mathrm{SiC}$ abrasive paper, manufactured by Buehler, Germany, designated as 600 grit, 1200 grit, and 1500 grit. Finally the samples were cleaned with ethanol in an ultrasonic bath for an approximated time of 14 minutes and dried with air.

\subsection{Immersion test}

Immersion tests were conducted in two steps. These conditions are based on Italian decree (D.M. 21-031973) and the procedure described by G. Herting et al. [12]. In the first step, the samples of AISI 430 steel with three different surface finishes were immersed in simulated food at $25^{\circ} \mathrm{C}$ and $60^{\circ} \mathrm{C}$ and left exposed during 4 to 10 days. In the second step, samples with the best surface finish (1500 grit) were immersed in the solution at temperature of $100^{\circ} \mathrm{C}$, for this stage the immersion time was $5 \mathrm{~min}, 15 \mathrm{~min}, 30 \mathrm{~min}, 60 \mathrm{~min}$ and $90 \mathrm{~min}$.

\subsection{Analysis of $\mathrm{Fe}, \mathrm{Cr}$ and $\mathrm{Ni}$ release ions}

In order to determine the concentration of $\mathrm{Fe}, \mathrm{Cr}$ and $\mathrm{Ni}$ ions released from AISI 430 steel, the final solutions obtained after immersing tests were analyzed by atomic absorption spectroscopy. The equipment used was a spectrum photometer Buck Scientific 210VGP.

\subsection{Electrochemical test}

To determine the electrochemical behavior of AISI 430 steel in contact with simulated food, the linear polarization resistance, and potentiodynamics polarization tests were performed. A potentiostat/galvanostat Gamry PC4 750 was used for this purpose. The tests were performed in a classic three-electrode cell configuration. AISI 430 steel was used as working electrode; a platinum mesh was a counter electrode and an $\mathrm{Ag} / \mathrm{AgCl}(3 \mathrm{M} \mathrm{KCl})$ as a reference electrode. The electrolytic solution was acetic acid $3 \% \mathrm{v} / \mathrm{v}$. The working area was $0.78 \mathrm{~cm}^{2}$. In all cases the cell was sealed to prevent leaks and evaporation of the solution. The working temperature of the electrochemical tests was $25 \pm 1^{\circ} \mathrm{C}$ and $60 \pm 1{ }^{\circ} \mathrm{C}$.

\subsection{Surface analysis}

The morphology of the surface of AISI 430 steel and the damage generated by contact with simulated food was observed using scanning electron microscope Quanta FEG 650.

\section{RESULTS AND DISCUSSION}

\subsection{Characterization of steel AISI 430}

Table 1 presents the composition of AISI 430 steel which was obtained through optical emission spectroscopy OES.

Table 1: Chemical composition of steel AISI 430 obtained by OES (\% mass).

\begin{tabular}{ccccccccc} 
& $\mathbf{C}$ & $\mathbf{M n}$ & $\mathbf{P}$ & $\mathbf{S}$ & $\mathbf{S i}$ & $\mathbf{C r}$ & $\mathbf{N i}$ & $\mathbf{F e}$ \\
\hline \multirow{2}{*}{ 430 SS } & 0.096 & 0.512 & 0.02 & $<0.150$ & 0.338 & 16.7 & 0.256 & 81.22 \\
\hline
\end{tabular}

After proper surface preparation, a chemical attack of the alloy was performed, using an acid solution with $10 \mathrm{~mL}$ of glycerin, $30 \mathrm{~mL}$ of $\mathrm{HCl}$ and $30 \mathrm{~mL}$ of $\mathrm{HNO}_{3}$ for an approximate time of 2 min according to the definitions given in the standard ASTM E-407. The microstructure was observed using an optical microscope Olympus GX71. As can be seen in the figure 1, the microstructure of the studied steel presents some inclusions and grains of ferrite with indistinct edges of grain. This result can be attributed to the cold 
rolled microstructure was mainly characterized by the deformed ferrite grains.

Figure 1: Steel AISI 430 microstructure

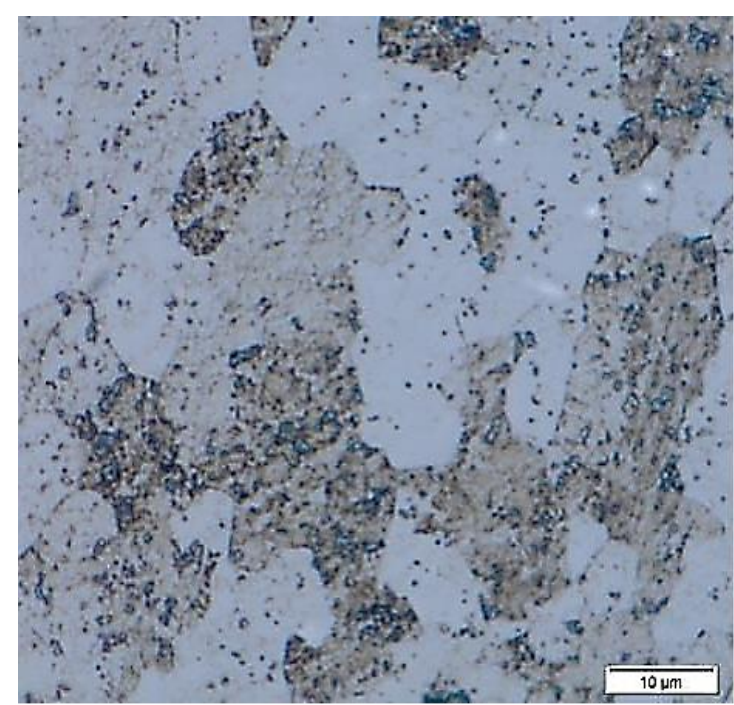

\subsection{Release of ions of $\mathrm{Fe}, \mathrm{Cr}$ and $\mathrm{Ni}$}

Atomic absorption (AA) spectroscopy analyses were performed with the final solutions of immersion test to obtain the $\mathrm{Fe}, \mathrm{Ni}$ and $\mathrm{Cr}$ ion concentration in each of the stages carried out. The results obtained are shown in the Table 2 and Table 3. The differences in the release of $\mathrm{Fe}, \mathrm{Ni}$ and $\mathrm{Cr}$ ions in immersion test can be used to describe the influence of the surface finishing of stainless steel in the releasing process. The obtained data clearly show that the finish with higher roughness (600) presented the greatest release of metal ions and with the lower roughness (1500) the minor release. It should emphasize that the release of $\mathrm{Ni}$ and $\mathrm{Cr}$ ions was only occurred for surface finishes of 600 and 1200. The correlation found between the ion release and the surface finishing is according to the reported previously in the literature [12, 17].

Table 2: Released metallic ions at $25^{\circ} \mathrm{C}$ and $60^{\circ} \mathrm{C}$ after a exposure time of 10 days.

\begin{tabular}{ccccc}
\hline $\mathbf{T}\left({ }^{\circ} \mathbf{C}\right)$ & Finish & $\mathbf{F e}(\mathbf{p p m})$ & $\mathbf{N i}(\mathbf{p p m})$ & $\mathbf{C r}(\mathbf{p p m})$ \\
\hline 25 & 600 & 0.4026 & -- & -- \\
\hline 25 & 1200 & 0.3305 & -- & -- \\
\hline 25 & 1500 & 0.2872 & -- & -- \\
\hline 60 & 600 & 1.2549 & 0.1329 & 0.0961 \\
\hline 60 & 1200 & 0.8244 & 0.1061 & 0.0593 \\
\hline 60 & 1500 & 0.8093 & -- & -- \\
\hline
\end{tabular}

The release of metal ion process is also time dependent (see Table 3). The data show changes in release rates during times of $5,15,30,60$ and 90 minutes at $100^{\circ} \mathrm{C}$. Similar results have been reported by Herting et al. [12,17]. This behavior can be attributed to the formation and dissolution of a thin layer of chromium oxide that temporarily protects the material. 
Table 3: Released metallic ions at $100^{\circ} \mathrm{C}$.

\begin{tabular}{crcc}
\hline time $(\mathbf{m i n})$ & Fe $(\mathbf{p p m})$ & Ni $(\mathbf{p p m})$ & $\mathbf{C r}(\mathbf{p p m})$ \\
\hline 5 & 0.7558 & -- & 0.0119 \\
\hline 15 & 0.4861 & -- & -- \\
\hline 30 & 0.6128 & -- & -- \\
\hline 60 & 0.7095 & -- & -- \\
\hline 90 & 0.6236 & -- & 0.0175 \\
\hline
\end{tabular}

\subsection{Electrochemical behavior}

The results of the polarization resistance tests are shown in Table 4 . As can be seen at temperature of $25^{\circ} \mathrm{C}$ samples of AISI 430 steel in contact with simulated food presented the highest values of polarization resistance. These results are consistent with the results obtained in similar releasing tests reported by the literature in which the lowest metal ions release occurs at room temperature [12]. On the other hand, samples exposed to the test solution at $60^{\circ} \mathrm{C}$ presented an increase in the polarization resistance with the immersion time, which shows an inverse relationship between corrosion resistance and the release of ions. This may be associated with the formation of a layer of chromium oxide that protects the material from corrosion, which is consistent with that reported in literature $[1,12,17,18]$.

Table 4: Linear polarization resistance values of AISI 430 steel in contact whit simulated food.

\begin{tabular}{cccc}
\hline $\begin{array}{c}\text { Temperature } \\
{ }^{\circ} \mathbf{C}\end{array}$ & Finish & $\begin{array}{c}\text { time } \\
\text { (days) }\end{array}$ & Rp $\left(\mathbf{k} \Omega / \mathbf{c m}^{2}\right)$ \\
\hline 25 & 600 & 10 & 69.0 \\
\hline 25 & 1500 & 10 & 1060.0 \\
\hline 60 & 600 & 4 & 15.2 \\
\hline 60 & 1500 & 4 & 54.1 \\
\hline 60 & 600 & 10 & 34.0 \\
\hline 60 & 1500 & 10 & 64.10 \\
\hline
\end{tabular}

Figures 2 and 3, Present the potentiodynamic polarization curves which show the corrosion susceptibility of the studied material in a simulated food solution. As can be seen, the material has a same trend for all studied conditions, which is very similar to that reported by Fattah-alhosseini and Vafaeian in [19] where the corrosion behavior of AISI 430 steel in contact with acidic media was studied.

In Figure 2, the effect of the immersion time in the electrochemical behavior of AISI 430 steel exposed to the simulated food at a temperature of $25^{\circ} \mathrm{C}$ can be seen. The samples exposed for 10 days have displacements for the corrosion potential, the active-passive transition potential and the pitting potential regarding samples exposed for 4 days. Passive region of the samples exposed for 10 days is more stable, which is observed in a wider potential gap with respect to the samples exposed for 4 days.

The effect of temperature on the electrochemical behavior of AISI 430 steel exposed to simulated food for 10 days can be seen in Figure 3. In this figure can be seen that the metal dissolution process is accelerated by exposing the steel at a temperature at $60^{\circ} \mathrm{C}$, therefore less energy is required to achieve the breakdown of the passive layer. Likewise, can be seen a shift to the right in the current density of the samples exposed to $60^{\circ} \mathrm{C}$. Also, the surface finish has an effect on the corrosion rate, since, These surface irregularities generated by grinding process cause a significant increase in surface roughness and consequently an increase in the contact area with the medium, which should have contributed to the decrease in corrosion resistance [20]. 


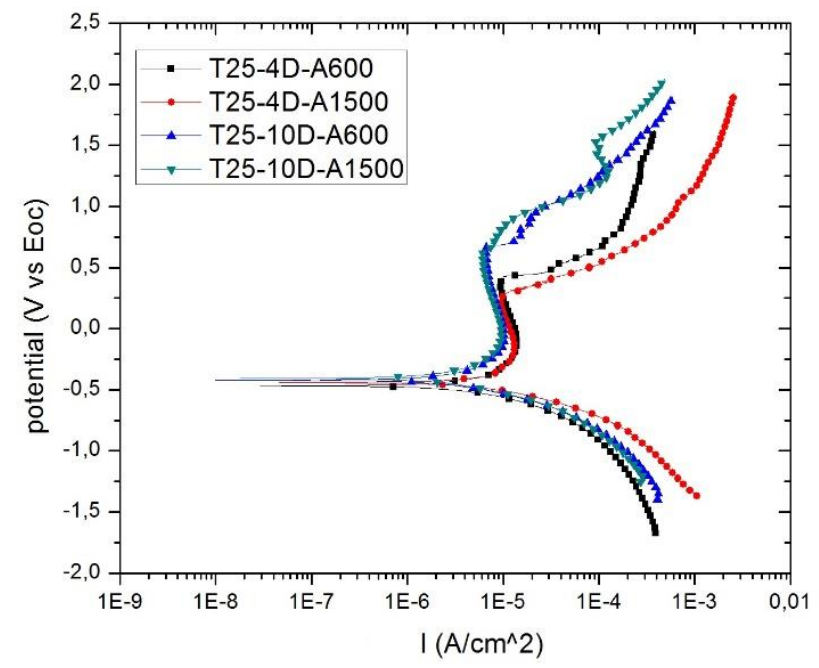

Figure 2: Potentiodynamic curves of AISI 430 steel in contact with simulated food obtained at $25^{\circ} \mathrm{C}$.

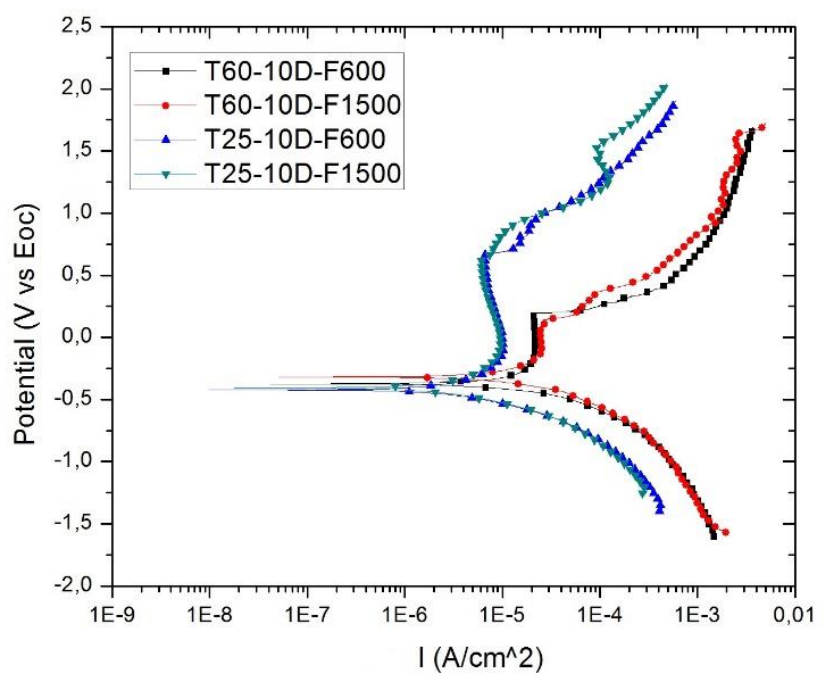

Figure 3: Potentiodynamic curves of AISI 430 steel in contact with simulated food obtained at 25 and $60^{\circ} \mathrm{C}$ after 10 days of immersion.

From the potentiodynamic curves of Figure 3 the corrosion rate was calculated applying the Tafel method on the cathodic zone (table 5). As can be seen, the higher corrosion rate occurred in AISI 430 steel with surface finish 600 samples, this is regarding to the largest exhibition area presenting these samples. Similarly, can be seen, that the corrosion rates increased with the temperature increase. These results correlated with that found in the test of ion releasing, where it was found that higher temperatures increased amount of released ions [12].

A characterization of the surface of tested samples was performed in order to establish the type of occurred damage. It was found that the main mechanism of corrosion was pitting as illustrated in Figure 4 which presents the surface of the samples tested at $25^{\circ} \mathrm{C}$ with different surface finishing and exposure times. The samples with surface finish of 600 exposed for 4 days shows a higher number of pits (Figure $4 a$ ) that the same sample exposed for 10 days (Figure 4C). These results confirm the obtained conclusions from polarization curves (see Figure 2). The same conclusion is true for the samples with surface finish 1500 (Figure 4b and 4D). 
Table 5: Corrosion rates of AISI 430 steel in contact with simulated food.

\begin{tabular}{|c|c|c|c|c|c|}
\hline $\begin{array}{c}\text { Temperature } \\
{ }^{\circ} \mathrm{C}\end{array}$ & Finish & time (days) & $\begin{array}{l}\mathbf{E}_{\text {corr }} \\
(\mathrm{mV})\end{array}$ & $I_{\text {corr }}\left(\mu \mathrm{A} / \mathrm{cm}^{2}\right)$ & $\begin{array}{c}\mathbf{V}_{\text {corr }} \\
(\mathrm{mpy})\end{array}$ \\
\hline \multirow{2}{*}{25} & 600 & \multirow{2}{*}{10} & -422 & 2.700152 & 0.020806 \\
\hline & 1500 & & -407 & 0.179215 & 0.001381 \\
\hline \multirow{2}{*}{60} & 600 & \multirow{2}{*}{10} & -374 & 2.720299 & 0.020961 \\
\hline & 1500 & & -319 & 0.803517 & 0.006191 \\
\hline
\end{tabular}
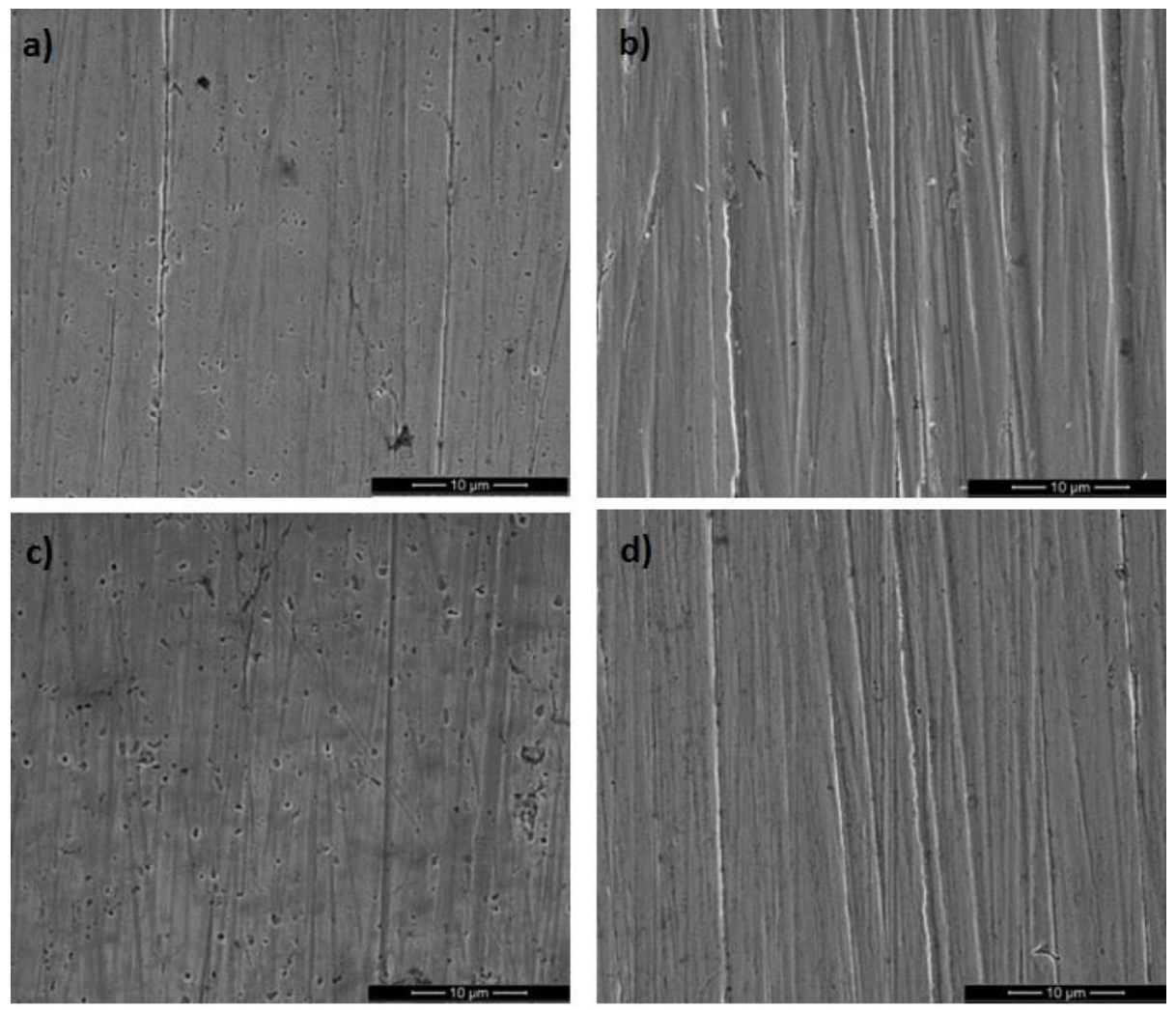

Figure 4: SEM micrographs of AISI 430 steel in contact with simulated food at $25{ }^{\circ} \mathrm{C}$. a) finish $600-4$ days, b) finish 1500 - 4 days, c) finish 600 - 10 days d) finish 1500 - 10 days.

\section{CONCLUSIONS}

The results of atomic absorption spectroscopy showed that the release of ion increased with the increase with the increase of the alloy roughness and test temperature. Samples with surface roughness (finish 600 grit) and temperature of $60^{\circ} \mathrm{C}$ showed higher release with respect to the glossy surface (finish 1500 grit), due to the rougher surface would be easily pitted because the smooth surface has fewer places for pit nucleation and can quickly form a passive film preventing pit nucleation.

The highest chromium release was observed at a working temperature of $60^{\circ} \mathrm{C}$, however, It does not exceed the permitted limit, $0.1 \mathrm{mg} / \mathrm{L}$ according to Italian decree. The electrochemical obtained results showed the effect of the temperature and roughness in increasing of the corrosion rate. In addition, it was found that the immersion time shifts the pitting potentials, which increase the corrosion in AISI 430 steel.

Steel AISI 430 is appropriate to be used in applications involving food contact, provided to ensure a fine surface finish and to avoid the exposure to high temperatures for prolonged times. 


\section{BIBLIOGRAPHY}

[1] HERTING, G., ODNEVALL WALLINDER, I, LEYGRAF, C. "Metal release from various grades of stainless steel exposed to synthetic body fluids", Corrosion Science, v 49, n. 1, pp. 103-111, January 2007.

[2] HERTING, G., ODNEVALL WALLINDER, I, LEYGRAF, C. "A Comparison of Release Rates of Cr, $\mathrm{Ni}$, and Fe from Stainless Steel Alloys and the Pure Metals Exposed to Simulated Rain Events", Journal of Electrochemical Society, v 152, n. 1, pp. B23-B29, 2005.

[3] OKAZAKI, Y., GOTOH, E. "Comparison of metal release from various metallic biomaterials in vitro", Biomaterials, v. 26, Issue 1, pp. 11-21, January 2005.

[4] LUNDIN, M., HEDBERG, Y., JIANG, T. "Adsorption and protein-induced metal release from chromium metal and stainless steel", Journal of Colloid and Interface Science, v. 366, n. 1, pp. 155-164, January 2012.

[5] DALIPI, R., BORGESE, L., CASAROLI, A., "Study of metal release from stainless steels in simulated food contact by means of total reflection X-ray fluorescence", Journal of Food Engineering, v. 173, pp. 8591, March 2016,

[6] PROVERBIO, E., BONACCORSI, L.M., "Erosion-corrosion of a stainless steel distillation column in food industry", Engineering Failure Analysis, v. 9, n. 6, pp. 613-620, December 2002.

[7] ZUMELZU, E., CABEZAS, C. "Observations on the influence of cleaners on material corrosion in the food industry", Materials Characterization, v. 37, n. 4, pp. 187-194, October 1996.

[8] HILBERT, L.R., BAGGE-RAVN, D., KOLD, J., et al., "Influence of surface roughness of stainless steel on microbial adhesion and corrosion resistance", International Biodeterioration \& Biodegradation, v. 52, n. 3, pp. 175-185, October 2003.

[9] JULLIEN, C., BÉNÉZECH, T., CARPENTIER, B., et al.,"Identification of surface characteristics relevant to the hygienic status of stainless steel for the food industry", Journal of Food Engineering, v. 56, n. 1, pp. 77-87, January 2003.

[10] FLINT, S.H., BROOKS, J.D., BREMER, P.J. "Properties of the stainless steel substrate, influencing the adhesion of thermo-resistant streptococci", Journal of Food Engineering, v. 43, n. 4, pp. 235-242, March 2000.

[11] CESCHINI, L., CHIAVARI, C., LANZONI, E., et al.,"Low-temperature carburised AISI 316L austenitic stainless steel: Wear and corrosion behavior", Materials \& Design, v. 38, pp. 154-160, June 2012.

[12] HERTING, G., ODNEVALL WALLINDER, I., LEYGRAF, C., "Corrosion-induced release of chromium and iron from ferritic stainless steel grade AISI 430 in simulated food contact", Journal of Food Engineering, v. 87, Issue 2, pp. 291-300, July 2008.

[13] DECRETO MINISTERIALE 21/03/1973, Hygienic Conditions of Packaging, Containers and Articles Intended to Come into Contact with Foodstuffs or with Substances of Human Use Gazzetta Ufficiale, Italy (1973)

[14] ALVARADO-GAMEZ, A., BLANCO-SAENZ, R., MORA-MORALES, E. "El cromo como elemento esencial en los humanos", Revista Costarricense de Ciencias Médicas, v. 23, n. 1-2, pp. 55-68, 2002.

[15] KAMERUD, K. L., HOBBIE, K. A., ANDERSON K. A., "Stainless Steel Leaches Nickel and Chromium into foods during cooking", Journal of Agricultural and Food Chemistry, v. 61 pp. 9495-9501, 2013.

[16] ANTICO, A. SOANA, R. "Nickel sensitization and dietary nickel are a substantial cause of symptoms provocation in patients with chronic allergic-like dermatitis syndromes", Allergy Rhinol, v. 1, 6, n. 1, pp 56632015.

[17] HERTING, G., LINDSTRÖM, V., ODNEVALL WALLINDER, I., et al.,"Multi-analytical investigation of stainless steel grade AISI 420 in simulated food contact", Journal of Food Engineering, v. 93, Issue 1, pp. 23-31, July 2009.

[18] HERTING, G., WALLINDER, I.O., LEYGRAF, C., "Factors that influence the release of metals from stainless steels exposed to physiological media", Corrosion Science, v. 48, n. 8, pp. 2120-2132, August 2006. [19] FATTAH-ALHOSSEINI, A., VAFAEIAN, S. "Effect of solution $\mathrm{pH}$ on the electrochemical behaviour of AISI 304 austenitic and AISI 430 ferritic stainless steels in concentrated acidic media", Egyptian Journal of Petroleum, v. 24, n. 3, pp. 333-341, September 2015. 
[20] PELTZ, J. S., ROSSA BELTRAN V., KUNST A R., BRANDOLT C., FRAGA MALFATTI, C. "Effect of the shot peening process on the corrosion and oxidation resistance of AISI 430 stainless steel", Materials Research, v.18, n. 3, pp. 538-545, June 2015. 